\title{
ANALISIS PENGARUH KEPEMIMPINAN TRANSFORMASIONAL DAN KEPEMIMPINAN TRANSAKSIONAL TERHADAP KEPUASAN KERJA ASISTEN APOTEKER DI RUMAH SAKIT BUDI KEMULIAAN BATAM
}

\author{
AZNEDRA \\ Dosen Fakultas Ekonomi Program Studi Akuntansi \\ Universitas Riau Kepulauan
}

\begin{abstract}
Abstrak
Penelitian ini bertujuan untuk menganalisis pengaruh gaya kepemimpinan terhadap kepuasan kerja, dengan mengukur pengaruh gaya kepemimpinan transformasional dan kepemimpinan transaksional terhadap kepuasan kepuasan kerja. Apakah ada pengaruh yang positif dan signifikan dari gaya kepemimpinan yang dikumpulkan secara metode koesioner, yaitu multi factor leadership questioner (MLQ) untuk mengukur persepsi kepuasan kerja. Populasi penelitian ini adalah asisten apoteker di Rumah Sakit Budi Kemuliaan Batam. Jumlah sampel sebanyak 80 orang responden yang diambil dengan teknik proportional random sampling. Metode analisis adalah kualitatif dan kuantitatif. Analisis kuantitatif yang dilakukan dengan menggunakan uji regrsi berganda dengan uji hipotesis yang ditetapkan pada tingkat 5\%.

Berdasarkan hasil penelitian ini diperoleh persamaan regresi sebagai berikut : $\mathrm{Y}=55,111$ 0,051 X1 - 0,098 X2 + 0,936 X3 dari persamaan tersebut diketahui gaya kepemimpinan transformasional dan kepemimpinan transaksional mempunyai pengaruh yang positif dan signifikan terhadap kepuasan kerja dengan besar pengaruh yang berbeda. Kepemimpinan transformasional mempunyai pengaruh yang lebih besar terhadap kepuasan kerja dibandingkan dengan kepemimpinan transaksional.

Kata kunci : Kepemimpinan transformasional, kepemimpinan transaksional, kepuasan kerja.

Abstract

This study aimed to analyze the influence of leadership style on job satisfaction, by measuring the effect of transformational leadership style and transactional leadership to satisfaction of job satisfaction. Is there a positive and significant effect of leadership style collected koesioner methods, namely multi-factor leadership questionnaire (MLQ) to gauge perceptions of job satisfaction. The study population was an assistant pharmacist at Hospital Budi Glory Batam. The total sample of 80 respondents were taken by proportional random sampling technique. Method is a qualitative and quantitative analysis. Quantitative analysis was performed by using multiple regrsi test to test the hypothesis set at $5 \%$ level.

Based on these results the following regression equation: $\mathrm{Y}=55.111$ to $0.051 \mathrm{X} 1-\mathrm{X} 20.098$ $+0.936 \mathrm{X} 3$ of the equation known transformational leadership style and transactional leadership has a positive and significant effect on job satisfaction with a different influence. Transformational leadership has a greater influence on job satisfaction compared to transactional leadership.
\end{abstract}

Keywords: Transformational leadership, transactional leadership, job satisfaction

PENDAHULUAN 
Rumah sakit yang merupakan sarana pelayanan kesehatan individu dan masyarakat saat ini telah berkembang menjadi kesatuan sistem pelayanan kesehatan yang mencakup aspek promotif, preventif dan rehabilitative. Rumah Sakit Budi Kemuliaan Batam merupakan salah satu rumah sakit terbesar di Batam yang berperan utama didalam meningkatkan tingkat kesehatan masyarakat. Rumah Sakit Budi Kemuliaan Batam mengemban tugas dan tanggung jawab yang sangat berat, disamping mengemban tugas peningkatan kesehatan masyarakat berdasarkan undang-undang kesehatan, juga dituntut untuk memberikan pelayanan yang terbaik kepada masyarakat, murah dan nyaman, sehingga memberikan kepuasan masyarakat.

Rumah Sakit merupakan organisasi yang sangat unik dan kompleks. Dikatakan unik karena rumah sakit menghasilkan jasa pelayanan perhotelan sekaligus jasa pelayanan kesehatan kepada pasien rawat inap dan rawat jalan. Dikatakan kompleks karena rumah sakit merupakan suatu organisasi padat karya dengan latar belakang pendidikan karyawan yang berbeda. Memadupadankan keunikan dan ke kompleksan merupakan tantangan yang tidak mudah dalam menjalankan sebuah rumah sakit.

Bagian Farmasi adalah salah satu bagian yang ada di Rumah Sakit Budi Kemuliaan Batam, yang mempunyai tugas utama melayani pasien yang datang berobat baik untuk rawat jalan maupun untuk rawat inap. Berdasarkan standar pelayanan yang harus dilakukan oleh seorang asisten apoteker maka seorang asisten apoteker harus melayani pasien sesuai SOP.

Berdasarkan rencana kerja Rumah Sakit Budi Kemuliaan Batam tahun 2014 dapat diketahui bahwa seorang asisten apoteker harus melayani resep pasien 10 orang. Berdasarkan data bagian humas untuk periode tahun 2014, dapat diketahui bahwa dari seluruh pasien yang pernah berobat dan dirawat di Rumah Sakit Budi Kemuliaan batam, masih banyak keluhan pasien yang tidak merasa nyaman dan puas terhadap pelayanan yang mereka terima.
Apotek merupakan sarana pelayanan kesehatan masyarakat yang wajib menyediakan, menyimpan dan menyerahkan perbekalan farmasi yang bermutu baik. Pelayanan kefarmasian yang dilakukan oleh apoteker di apotek merupakan bentuk pelayanan dan tanggung jawab langsung profesi apoteker dalam melakukan pekerjaan kefarmasiannya untuk meningkatkan kualitas hidup pasien.

$\begin{array}{crr} & \text { Berdasarkan Peraturan } & \text { Pemerintah } \\ \text { No.51 tahun } 2009 \text { tentang } & \text { Pekerjaan }\end{array}$

Kefarmasian, yangdimaksud dengan apotek

adalah suatu sarana pelayanan kefarmasian tempat dilakukannya praktek kefarmasian oleh apoteker. Pekerjaan kefarmasian yang dimaksud adalah pembuatan termasuk pengendalian mutu sediaan farmasi, pengamanan, pengadaan, penyimpanan dan pendistribusi atau penyaluran obat, pengelolaan obat, pelayanan obat atas resep dokter, pelayanan informasi obat, serta pengembangan obat, bahan obat dan obat tradisional. Pekerjaan kefarmasian juga meliputi dalam pengadaan sediaan farmasi, produksi sediaan farmasi, distribusi atau penyaluran sediaan farmasi, dan pelayanan dalam sediaan farmasi (7).

Berdasarkan data-data dari bagian humas yang diuraikan diatas, terlihat bahwa masih terdapat kinerja bagian farmasi yang belum sesuai dengan standar pelayanan farmasi dan belum sesuai dengan rencana kerja Rumah Sakit Budi Kemuliaan Batam tahun 2014. Kinerja yang belum sesuai ini mengindikasikan adanya ketidakpuasan kerja (kepuasan kerja rendah)

Tingginya tingkat kepuasan kerja di suatu perusahaan/organisasi menandakan perusahaan/organisasi tersebut dikelola dengan baik. Sedangkan rendahnya tingkat kepuasan kerja menandakan sebaliknya. Hal ini dapat diindikasikan oleh banyaknya keluhan dari karyawan, rendahnya performance, tingginya tingkat turnover karyawan, rendahnya kedisplinan dan masalah-masalah lainnya yang 
mungkin dihadapi oleh perusahaan tersebut (Lussier, 2010 dalam Noegraha, 2009)

Pada beberapa peneliti biasanya percaya bahwa hubungan antara kepuasan kerja dengan kinerja pekerjaan adalah mitos manajemen, tetapi, sebuah tinjauan dari 300 penelitian menunjukkan bahwa korelasi tersebut cukup kuat. Ketika data produktivitas dan kepuasaan secara keseluruhan dikumpulkan untuk organisai yang mempunyai karyawan yang lebih puas cenderung lebih efektif bila diandingkan organisasi yang mempunyai karyawan yang kurang puas (Robbins dan judge, 2008 :113)

Kepuasan kerja (Job satisfaction) dapat didefenisikan sebagai suatu perasaan positif tentang pekerjaan seseorang yang merupakan hasil dari sebuah evaluasi karakteristiknya. Seseorang dengan tingkat kepuasan kerja yang tinggi memiliki perasaanperasaan positif tentang pekerjaan tersebut, sementara seseorang yang tidak puas memiliki perasaan-perasaan negatif tentang pekerjaan tersebut. Ketika individu membicarakan sikap karyawan, yang sering dimaksudkan adalah kepuasan kerja (Robbins dan Judge, 2008 :99)

Kepuasan kerja sangat berperan, karena dapat membantu perusahaan/organisasi untuk memahami bagaimana reaksi karyawan atas pekerjaan yang mereka lakukan dan memperkirakan dampaknya pada perilaku mereka di masa mendatang.

Kebijakan pimpinan Rumah Sakit Budi Kemuliaan Batam, khususnya bagian farmasi mencerminkan kepemimpinan transaksional, hal ini berdasarkan fakta yang ada yaitu sebagai berikut :

- Untuk mendapatkan memahami yang utuh tentang ketidakpuasaan pasien kepada rumah sakit (khususnya pasien rawat inap), dilakukan pengamatan langsung dilapangan. Dalam pengamatan ini, asisten apoteker yang menagani pasien melakukan semua pekerjaannya sesuai denga SOP maupun standar pekerjaan.
- Pada akhir bulan, Bagian farmasi mengadakan pertemuan yang diwakili oleh masing-masing koordinator apotek. Setiap koordinator akan mengemukakan perbagai permasalahan yang dihadapi disetiap apotek dan disimpulkan langkah-langkah yang harus diambil serta langkah-langkah perbaikan untuk pencapaian pelayanan yang baik.

- Pada beberapa kesempatan Apoteker dan asisten apoteker akan diikutkan untuk mengikuti seminar-seminar, pelatihanpelatihan dengan tujuan peningkatana kemampuan dibidangnya.

- Bagian farmasi, berdasarkan aturan yang ada akan menaikkan atau menurunkan atau mempertahankan grading pegawai sesuai hasil kerja asisten apoteker tersebut.

- Bagian farmasi, berdasarkan aturan yang ada akan memberikan teguran dan sanksi (mulai dari yang ringan sampai yang berat) terhadap pegawai.

Berdasarkan uraian tersebut diatas, maka penelitian ini berusaha untuk menganalaisis pengaruh kepemimpinan transformasional dan kepemimpinan transaksional terhadap kepuasan kerja di Bagian Farmasi Rumah Sakit Budi Kemuliaan Batam.

\section{Penelitian Terdahulu}

Penelitian yang dilakukan oleh Penelitian yang dilakukan oleh B. Maptuah Rahmi, dengan judul : "Pengaruh Kepemimpinan Trasformasional terhadap Organizational Citizenship Behavior dan Komitmen Organisasional dengan Mediasi Kepuasan Kerja Guru SMA Negeri Di Kabupaten Lombok Timur." Hasil penelitian menunjukkan bahwa kepemimpinan transformasional berpengaruh positif dan signifikan terhadap organizational citizenship behavior, namun tidak signifikan terhadap komitmen organisasional

Penelitian yang dilakukan oleh Rina Laurensia (2006) menunjukkan bahwa terdapat pengaruh positif dan signifikan antara kepemimpinan transformasional terhadap kepuasan kerja.Kepemimpinan transformasional dan transaksional, secara bersama-sama, berkorelasi secara positif dan 
signifikan dengan kepuasan kerja (Andarika dan Tondok, 2004

\section{LANDASAN TEORI}

\section{Kepemimpinan}

Kepemimpinan (leadership) adalah kemampuan untuk mempengaruhi suatu kelompok guna mencapai sebuah visi atau serangkaian tujuan yang ditetapkan (Robbins dan Judge, 2008 :49)

Kepemimpinan adalah pengaruh, kemampuan memperoleh pengikut dan menjadi seorang yang siikuti orang lain dengan senang hati dan penuh keyakinan (Maxwell, 2006, dalam wahjono, $2010: 266$ )

Kepemimpinan adalah suatu proses yang mempengaruhi aktivitas kelompok yang diatur untuk mencapai tujuan bersama (Rauch dan Behling, 1984, dalam Danim dan Suparno, $2009: 2$ )

Kepemimpinan yang berhasil akan sangat dipengaruhi oleh perilaku pimpinan, dimana seorang pemimpin melibatkan atau menempatkan diri pada proses memberi arah dan mengkordinasi tugas-tugas anggota kelompoknya (Sultiyani dan Rosidah, 2006 : 197)

Kepemimpinan merupakan faktor penting dalam kehidupan organisasi, karena kemampuan seorang pemimpin dalam mempengaruhi karyawannya menjadi faktor yang menentukan sukses tidaknya suatu organisasi.

Seorang pemimpin harus mampu mengembangkan strategi untuk mempengaruhi bawahan sesuai yang diinginkan organisasi. Dengan kata lain, maju mundurnya suatu organisasi sangat tergantung seberapa baik pemimpin memainkan perannya atau kepemimpinannya, agar organisasi tersebut survive serta terus berkembang. Hal ini dikarenakan pemimpinlah yang menjadi koordinator yang akan membawa organisasi pada puncak keberhasilan.

Mcgregor Burns mengidentifikasi dua jenis kepemimpinan yaitu kepemimpinan transaksional dan kepemimpinan transformasional. Kepemimpinan transaksional mencakup hubungan pertukaran antara pemimpin dan pengikut. Kepemimpinan transformasional lebih mendasarkan pada pergeseran nilai dan kepercayaan pemimpin, serta kebutuhan pengikutnya (Wahjono, 2010 :296)

Kepemimpina didefinisikan sebagai suatu proses pengaruh sosial dimana pemimpin mengusahakan partisipasi sukarela dari para bawahan dalam suatu usaha untuk mencapai tujuan organisasi (Kreitner dan Kinicki, 2003 : 299)

Kepemimpinan yang berhasil akan sangat dipengaruhi oleh perilaku pimpinan, dimana seorang pemimpin melibatkan atau menempatkan diri pada proses memberi arah dan mengkordinasikan tugas-tugas anggota kelompoknya (Sulistiyani dan Rosidah, 2005 : 197)

Ketika para pemimpin merasa bersemangat, atusias, dan aktif mereka lebih mungkin untuk memberi energi pada bawahanbawahan mereka dan menyampaikan rasa efektifitas, kompetensi, optimisme dan kegembiraan (Robbins dan Judge, 2008 : 342)

Menurut John C Maxwell (2006), kepemimpinan adalah pengaruh, kemampuan memperoleh pengikut, dan menjadi seseoang yang diikuti orang lain dengan senang hati dan penuh keyakinan (Wahjono, $2010: 266$ ).

Menurut Harsey dan Blanchard (1998), leadership is the process of directing and influencing the task-related activities of an group members. Konsep ini menggambarkan bahwa seorang pemimpin harus berusaha secara optimal menggerakkan bawahan, sehingga mereka dapat bekerjasama secara produktif untuk mencapai tujuan (Danim dan Suparno. 2009: 41)

Kepemimpinan juga merupakan energi yang dapat menggerakkan, menuntun dan menjaga aktivitas orang sehingga tujuan organisasi dapat dicapai (Danim dan Suparno, 2009 :41).

Pada dasarnya, kepemimpinan merupakan kemampuan pemimpin untuk mempengaruhi karyawan dalam sebuah organisasi. Dalam memberikan penilaian terhadap gaya kepemimpinan yang diterapkan pemimpin, karyawan melakukan proses kognitif untuk menerima, mengorganisasikan, dan memberi penafsiran terhadap pemimpin (Solso, 2008, dalam Tondok, 2009) 
Kepemimpinan merupakan faktor penting dalam kehidupan organisasi, karena kemampuan pemimpin dalam mempengaruhi karyawannya menjadi faktor yang menentukan sukses tidaknya suaru organisasi. Seorang pemimpin harus mampun mengembangkan strategi untuk mempengaruhi bawahan sesuai yang diinginkan organisasi. Dengan kata lain, maju mundurnya suatu organisasi sangat tergantung seberapa baik pemimpin memainkan perannya atau kepemimpinannya, organisasi tersebut dapat survive serta terus berkembang. Hal ini pemponlah yang menjadi koordinator yang akan membawa organisasi oada puncak keberhasilan.

Mcgregor Burns mengidentifikasi dua jenis kepemimpinan yaitu kepemimpinan transaksional mencakup hubungan pertukaran antara pemimpin dan pengikut. Kepemimpinan transformasional lebih mendasar pada pergeseran nilai dan kepercayaan pemimpin, serta kebutuhan pengikitnya (Wahjono, 2010 : 296).

Kedua jenis kepemimpinan ini saling melengkapi, tetapi tidak berarti keduanya sama penting. Kepemimpinan transformasional lebih unggul daripada kepemimpinan transaksional dan menghasilkan tingkat upaya dan kinerja para pengikutnya yang melampaui apa yang bisa dicapai kalau hanya pendekatan transaksional saja yang diterapkan (Robbins dan Judge, 2008 : 91).

Kepemimpinan transformasioanal seringkali dipersandingkan dengan kepemimpinan transaksional, karena setiap perilaku kepemimpinan melahirkan transaksi antara pemimpin dan yang dipimpin. Meskipun ada perbedaan esensial antara kedua jenis kepemimpinan tersebut, perbedaan itu bukan atas dasar tujuan yang dikehendaki, melainkan pada perilaku, dimana yang satu mengedepankan ke arah transformasi, sementara yang lainnya mengarah ke transaksi (Danim dan Suparno, 2009 : 53-54)

Menurut Bass yang dikutip oleh Harsiwi (2005), kepemimpinan transaksional adalah kepemimpinan yang memilihara atau melanjutkan status quo, sedangkan kepemimpinan transformasional melibatkan perubahan dalam organisasi, bertentangan dengan kepemimpinan yang dirancang untuk memeilihara staus quo (Danim dan Suparno, $2009: 53-54)$

Kepemimpinan juga merupakan penggerak bagi sumber daya dan alat-alat yang dimiliki oleh perusahaan. Definisi kepemimimpinan, menurut Terry (Kartono 2008: 38), "Kepemimpinan adalah aktifitas mempengaruhi orang-orang agar mereka suka berusaha mencapai tujuan kelompok".

Hasil tinjauan penulis-penulis lain mengungkapkan bahwa para penulis manajemen sepakat bahwa kepemimpinan adalah proses mempengaruhi aktifitas seseorang atau sekelompok orang untuk mencapai tujuan dalam situasi tertentu. Menurut Ordway Teod dalam bukunya The Art Of Leadershi (Kartono 1998 : 38) "Kepemimpinan merupakan kegiatan mempengaruhi orang-orang bekerja sama untuk mencapai tujuan yang mereka inginkan,

Kepemimpinan dapat terjadi dimana saja, asalkan seseorang menunjukkan kemampuannya mempengaruhi perilaku orang lain ke arah tercapainya suatu tujuan tertentu. Sedangkan Young dalam Kartono (1998) mendefinisikan bahwa "Kepemimpinan adalah bentuk dominasi yang didasari atas kemampuan pribadi yang sanggup mendorong atau mengajak orang lain untuk berbuat sesuatu, berdasarkan akseptasi atau penerimaan oleh kelompoknya dan memiliki keahlian khusus yang tepat bagi situasi tertentu". Berdasarkan pendapat di atas dapat disimpulkan bahwa kepemimpinan adalah kemampuan mempengaruhi bawahan atau kelompok untuk bekerja sama mencapai tujuan organisasi atau kelompok.

\section{Kepemimpinan Transformasional dan Kepemimpinan Transaksional}

Pemimpin transaksional adalah pemimpin yang mengarahkan para pengikutnya yang telah ditetapkan dengan cara memperjelas peran dan tugas mereka. Pemimpin transformasional adalah pemimpin yang menginspirasi para pengikutnya untuk mengenyampingkan kepentingan pribadi mereka demi kebaikan organisasi dan mereka mampu memiliki pengaruh yang luar biasa pada diri para pengikutnya.

Pemimpin transformasional menaruh perhatian terhadap kebutuhan pengembangan diri para pengijutnya, mengubah kesadaran para pengikutnya atas isu-isu yang ada dengan cara membantu orang lain memandang masalaha 
lama dengan cara yang baru, serta mampu menyenangkan hati dan menginspirasi para pengikutnya untuk bekerja keras guna mencapai tujuan-tujuan bersama (Robbins dan Judge, $2008:$ 90).

Kepemimpinan transaksional dan transformasional hendaknya tidak dipandang sebagai pendekatan yang saling bertentangan. Kedua jenis kepemimpinan ini saling melengkapi, tetapi tidak berarti keduanya sama penting. Kepemimpinan transfromasional lebih unggul daripada kepemimpinan transaksional dan menghasilkan tingkat upaya dan kinerja para pengikutnya yang melampaui apa yang bisa dicapai kalau hanya pendekatan transaksional saja yang diterapkan (Robbins dan Judge, 2008 : 91)

Kepemimpinan transformasional seringkali dipersandingkan dengan kepemimpinan transaksional, kaena setiap perilaku kepemimpinan melahirkan traksasi antara pemimpin dan yang dipimpin.

Ada perbedaan esensial antara kedua jenis kepemimpinan tersebut, perbedaan itu bukan atas dasar tujuan yang dikehendaki, melainkan pada perilaku, dimana yang satu mengedepankan kearah transformasi. Sementara yang lainnya mengarah ke transaksi (Danim dan Suparno, 2009 : 53-54)

Terkait dengan kepemimpinan, bahwa salah satu faktor yang ingin dicapai dari kepemimpinan traksaksional dan transformasional adalah tercapainya kepuasan kerja karyawan. Kepuasan kerja dipandang dapat mempengaruhi jalannya organisasi secara keseluruhan.

Sebagai salah satu faktor penentu kinerja organisasi, kepuasan kerja merupakan faktor yang sangat kompleks karena kepuasan kerja dipengaruhi berbagai faktor, diantaranya kepemimpinan

Menurut Bass (1998) dalam Swandari (2003) mendefinisikan bahwa "Kepemimpinan transformasional sebagai pemimpin yang mempunyai kekuatan untuk mempengaruhi bawahan dengan cara-cara tertentu (Yukl, 1989 : 224)". Dengan penerapan kepemimpinan transformasional bawahan akan merasa dipercaya, dihargai, loyal dan respek kepada pimpinannya.
Pada akhirnya bawahan akan termotivasi untuk melakukan lebih dari yang diharapkan. Sedangkan menurut O'Leary (2001) "Kepemimpinan transformasional adalah gaya kepemimpinan yang digunakan oleh seseorang manajer bila ia ingin suatu kelompok melebarkan

batas dan memiliki kinerja melampaui status dan mencapai serangkaian sasaran organisasi yang sepenuhnya baru".

Kepemimpinan transformasional pada prinsipnya memotivasi bawahan untuk berbuat lebih baik dari apa yang bisa dilakukan, dengan kata lain dapat meningkatkan kepercayaan atau keyakinan diri bawahan yang akan berpengaruh terhadap peningkatan kinerja.

Berdasarkan uraian diatas menyimpulkan bahwa kepemimpinan transformasional yang mencakup upaya perubahan terhadap bawahan untuk berbuat lebih positif atau lebih baik dari apa yang biasa dikerjakan yang berpengaruh terhadap peningkatan kinerja.

\section{Pengertian Kepuasan Kerja}

Kepuasan kerja adalah suatu perasaan positif tentang pekerjaan seseorang yang merupakan hasil dari sebuah evaluasi karakteristiknya (Robbins dan Judge 2008:107). Menurut Luthans (2006:243), terdapat lima dimensi kepuasan kerja, yaitu: pembayaran, pekerjaan itu sendiri, kesempatan promosi, supervisor, dan rekan kerja.

Kepuasan kerja dipandang dapat mempengaruhi jalannya organisasi secara kesekuruhan. Sebagai salah satu faktor penentu kinerja organisasi, kepuasan kerja merupakan faktir yang sangat kompleks karena kepuasan kerja dipengaruhi berbagai faktor, diantaranya kepemimpinan (judge dan Locke, 2005, dalam Tondok, 2005). Terkait dengan perilaku kepemimpinan, bahwa salah satu faktor yang ingin dicapai dari perilaku kepemimpinan transaksioanl dan transformasional adalah tercapainya kepuasan kerja karyawan.

Menurut sekaran (dalam Sugiyono, 2005 :47), kerangka berpikir merupakan model konseptual tentang bagaimana teori berhubungan dengan berbagai faktor yang telah diidentifikasi sebagai masalah yang penting. Dapat juga diartikan rangkaian penalaran dalam suatu kerangka berdasarkan pada premispremis untuk sampai pada simpulan-simpulan 
yang berakhit pada hipotesis yang akan diuji secara empiris.

Pada dasarnya seseorang dalam bekerja akan merasa nyaman dan setia pada perusahaan apabila dalam bekerja memperoleh kepuasan kerja sesuai dengan apa yang diinginkan. Kepuasaan kerja itu sendiri mempunyai dua kata yaitu kepuasan dan kerja. Kepuasan adalah sesuatu perasaan yang dialami seseorang, diamana apa yang diharapkan telah terpenuhi atau bahkan apa yang diterima melebihi apa yang diharapkan, sedangkan kerja merupakan usaha seseorang untuk mencapai tujuan dengan memperoleh pendapatan atau kompensasi dari kontribusinya di tempat pekerjaanya.

Kepuasan kerja (job satisfaction) dapat didefinisikan sebagai suatu perasaan positif tentang pekerjaan seseorang yang merupakan hasil dari sebuah evaluasi karakteristiknya. Seseorang dengan tingkat kepuasan kerja yang tinggi memiliki perasaan-perasaan positif tentang pekerjaan tersebut, sementara seseorang yang tidak puas memiliki perasaanperasaan negatif tentang pekerjaan tersebut. Ketika individu membicarakan sikap karyawan, yang sering dimaksudkan adalah kepuasaan kerja (Robbins dan Judge, 2008 : 99)

Kepuasaan kerja sebagai sikap positif atau negatif yang dilakukan individual terhadap pekerjaan mereka (Greenberg dan Baron, 2003 dalam Wibowo, 2008 :299)

Kepuasan kerja sebagai pemikiran, perasaan, dan kecendrungan tindakan seseorang, yang merupakan sikap seseorang terhadap pekerjaan (Vecchio, 1995 dalam Wibowo, 2008 :299)

Kepuasaan kerja sikap yang dimiliki pekerja tentang pekerjaan mereka (Gibson, 2000 dalam Wibowo, 2008 : 299-300)

Kepuasaan kerja mempengaruhi kinerja (Schab dan Cummings, 1970 dalam Pangesti, 2009)

Kepuasan kerja mempengaruhi kinerja (Schab dan Cummings, 1970 dalam Pangesti, 2009)

Kepuasaan kerja merupakan respons affective atau emosional terhadap berbagai segi pekerjaan seseorang (Kreitner dan Kinicki, 2001 dalam Wibowo, $2008: 300$ )
Kepuasaan kerja merupakan suatu perasaan yang mencerminkan sikap seseorang atas suatu pekerjaan. Sikap tersebut timbul dari persepsi mereka atas pekerjaannya, yang melibatkan aspek-aspek seperti besarnya upah atau gaji, kesempatan promosi, hubungan dengan rekan kerja, penempatan kerja, jenis pekerjaan, struktur organisasi perusahaan dan pengawasan (Hellriegel dan Slocum, 2004 dalam Noegraha, 2005)

Kepuasan kerja lebih mempengaruhi daripada kinerja mempengaruhi kepuasaan kerja (daniel J. Koys, 2001 dalam Luthans, 2006 :246) Apabila kepuasan kerja tinggi, maka karyawan akan bekerja sebaik mungkin sehingga menghasilkan kinerja yang baik (Kreitner, 1998 dalam Laurensia, 2006)

Kepuasaan kerja yang dirasakan individu akan berpengaruh terhadap kinerja individu tersebut karena pada umumnya suatu organisasi terfokus pada kinerja dan keuntungan, baik kinerja individu maupun kinerja organisional (Dollinger, 1997 dalam Pangesti, 2009)

Tingginya tingkat kepuasan kerja di suatu perusahaan/organisasi menandakan perusahaan/organisasi tersebut dikelola dengan baik. Sedangkan rendahnya tingkat kepuasan kerja menandakan sebaliknya. Hal ini dapat diindikasikan oleh banyaknya keluhan dari karyawan, rendahnya perfomance, tingginya tingkat turnover karyawan, rendahnya kedisiplinan dan masalah-masalah lainnya yang mungkin dihadapi oleh perusahaan tersebut (Lussier, 2002 dalam Noegraha, 2005).

Kepuasaan kerja sangat berperan, karena dapat membantu perusahaan/organisasi untuk memahami bagaimana reaksi karyawan atas pekerjaan yang mereka lakukan dan memperkirakan dampaknya pada perilaku mereka di masa mendatang.

Kepuasan kerja (job satisfaction) adalah keadaan emosional yang positif yang merupakan hasil dari evaluasi pengalaman kerja seseorang. Ketidakpuasan kerja muncul ketika

harapan seseorang tidak terpenuhi (Maltis dan Jackson,2006:121).

Kepuasan kerja mencakup dimensi yang bersifat intrinsik yaitu kepuasan yang diperoleh individu dari pelaksanaan 
pekerjaannya dan dimensi kepuasan bersifat ekstrinsik yaitu kepuasan yang didapat dari pihak eksternal.

Pada dasarnya seseorang dalam bekerja akan merasa nyaman dan setia pada perusahaan apabila dalam bekerja memperoleh kepuasan kerja sesuai dengan apa yang diinginkan.

Kepuasan kerja itu sendiri mempunyai dua kata yaitu kepuasan dan kerja. Kepuasan adalah sesuatu perasaan yang dialami oleh seseorang, dimana apa yang diharapkan telah terpenuhi atau bahkan apa yang diterima melebihi apa yang diharapkan, sedangkan kerja merupakan usaha seseorang untuk mencapai tujuan dengan memperoleh pendapatan atau kompensasi dari kontribusinya di tempat pekerjaannya.

Menurut Dole and Schroeder dalam Koesmono (2005:170) kepuasan kerja dapat didefinisikan sebagai perasaan dan reaksi individu terhadap lingkungan pekerjaannya, sedangkan menurut Testa dan Locke dalam Koesmono (2005:170) kepuasan kerja merupakan kegembiraan atau pernyataan emosi yang positif hasil dari penilaian salah satu pekerjaan atau pengalaman-pengalaman pekerjaan. Pada dasarnya makin positif sikap kerja makin besar pula kepuasan kerja, untuk itu berbagai indikator dari kepuasan kerja perlu memperoleh perhatian khusus agar pekerja dapat meningkatkan kinerjanya

Pada umumnya seseorang merasa puas dengan pekerjaannya karena berhasil dan memperoleh penilaian yang adil dari pimpinannya.

\section{Faktor-faktor yang Mempengaruhi Kepuasan Kerja \\ Schemerhorn dalam Wikipedia} (2008:1) mengidentifikasi lima aspek yang terdapat dalam kepuasan kerja, yaitu: pekerjaan itu sendiri (work it self), penyelia (supervision), teman sekerja (workers), promosi (promotion), gaji/upah (pay).

Aspek-aspek lain yang terdapat dalam kepuasan kerja disebutkan oleh Stephen Robins dalam Wikipedia (2008:1) yaitu: kerja yang secara mental menantang, ganjaran yang pantas, kondisi kerja yang mendukung, rekan kerja yang mendukung, kesesuaian kepribadian dengan pekerjaan.

\section{Konsep Kinerja}

Kinerja sering disebut performance, result (Cash and Fischer dalam Thoyib, A, 2005:69) yang berarti apa yang telah dihasilkan oleh individu karyawan. Kinerja (performance) adalah apa yang dilakukan atau tidak dilakukan oleh karyawan.

$$
\text { Menurut Mangkunegara dalam }
$$

Koesmono (2005:67) kinerja dapat didefinisikan sebagai hasil kerja secara kualitas dan kuantitas yang dapat dicapai oleh seseorang pegawai dalam melaksanakan tugas sesuai dengan tanggungjawab yang diberikan kepadanya. Soeprihantono dalam Koesmono (2005:170) mengatakan bahwa kinerja merupakan hasil pekerjaan seorang karyawan selama periode tertentu dibandingkan dengan berbagai kemungkinan, misalnya standard, target/sasaran/kriteria yang telah ditentukan terlebih dahulu dan telah disepakati bersama.

Menurut Robbins dalam Witjaksono (2003:20) mengatakan bahwa "employee performance is a function of the interaction of ability and motivation", maksudnya yang dihasilkan dari adanya interaksi antara kemampuan dan motivasi, dan jika situasi tersebut digabungkan dengan kemampuan karyawan maka akan mempengaruhi kinerja karyawan.

Selanjutnya Robbins menunjukkan dengan hal tersebut dalam suatu fungsi "Performance Ability x Motivation" artinya bahwa kinerja merupakan hasil interaksi antara kemampuan dan motivasi.

Penilaian kinerja adalah salah satu tugas penting untuk dilakukan oleh seorang manajer atau pimpinan. Dalam hubungannya dengan output (hasil yang didapat) kinerja dapat dilihat dari indikator-indikator berikut: kepatuhannya terhadap segala aturan yang telah ditetapkan dalam perusahaan, dapat melaksanakan tugasnya tanpa kesalahan (dengan tingkat kesalahan paling rendah) dan ketepatan dalam menjalankan tugasnya (Simamora,2004:327). Untuk lebih mempertajam indikator tersebut Gomes dalam Witjaksono (2003:22) mengemukakan tipe kriteria kinerja yang didasarkan atas deskripsi prilaku yang spesifik yaitu: Quantity of work, Quality of work, Creativeness, Cooperation, Dependability, Initiative, Personal qualitie.

Menurut T. Hani Handoko dalam Andraeni (2003:36-37) ada enam metode penilaian kinerja karyawan: Rating Scale, Checklist, metode peristiwa kritis (critical incident method), metode peninjauan lapangan 
(field review method), tes dan observasi prestasi kerja, method ranking

\section{Faktor-faktor yang mempengaruhi kinerja}

Kinerja merupakan suatu fungsi dari motivasi dan kemampuan. Agar tugas atau pekerjaan dapat diselesaikan, seseorang harus memiliki derajat kesediaan dan tingkat kemampuan tertentu. Kesediaan dan ketrampilan seseorang tidaklah cukup efektif untuk mengerjakan sesuatu tanpa pemahaman yang jelas tentang apa yang akan dikerjakan dan bagaimana mengerjakannya (Rivai dan Basri,2004:15).

Menurut Gibson, et al dalam Andraeni (2003:39-41), ada tiga perangkat variabel yang mempengaruhi perilaku dan prestasi kerja atau kinerja, yaitu: 1) Variabel individual, terdiri dari: (a) Kemampuan dan ketrampilan: mental dan fisik, (b) Latar belakang: keluarga, tingkat sosial, penggajian, (c) demografis: umur, asalusul, jenis kelamin. 2) Variabel organisasional, terdiri dari sumberdaya, kepemimpinan, imbalan, struktur dan desain pekerjaan. 3) Variabel psikologis terdiri dari persepsi, sikap, kepribadian, belajar dan motivasi.

Menurut Tiffin dan Mc. Cormick dalam Andraeni (2003:39-40) ada dua variabel yang dapat mempengaruhi kinerja, yaitu: Variabel individual, meliputi sikap, karakteristik, sifat-sifat fisik, minat dan motivasi, pengalaman, umur, jenis kelamin, pcndidikan, serta faktor individual lainnya, sedangkan variabel situasional meliputi: faktor fisik dan pekerjaan, terdiri dari; metode kerja, kondisi dan desain perlengkapan kerja, penataan ruang dan lingkungan fisik (penyinaran, temperatur, dan fentilasi) dan faktor sosial dan organisasi, meliputi: peraturan-peraturan organisasi, sifat organisasi, jenis latihan dan pengawasan, sistem upah dan lingkungan sosial.

Menurut Sutemeister dalam Andraeni (2003:40-41) mengemukakan pendapatnya bahwa kinerja dipengaruhi oleh dua faktor, yaitu: faktor Kemampuan: terdiri dari pengetahuan yang meliputi pendidikan, pengalaman, latihan dan minat, dan ketrampilan, meliputikecakapan dan kepribadian.

Faktor kedua adalah faktor motivasi: (a) Kondisi sosial: organisasi formal dan informal, kepemimpinan, (b) Serikat kerja kebutuhan individu: fisiologis, sosial dan egoistic, (c) Kondisi fisik : lingkungan kerja.

\section{Hubungan Gaya Kepemimpinan dan Kepuasan Kerja}

Sebagai salah satu faktor penentu kinerja organisasi maka kepuasan kerja merupakan faktor yang sangat kompleks karena kepuasan kerja di pengaruhi berbagai faktor diantaranya gaya kepemimpinan.

Pada dasarnya kepemimpinan merupakan kemampuan pemimpin untuk mempengaruhi karyawan dalam sebuah organisasi sehingga mereka

termotivasi untuk mencapai tujuan organisasi

\section{Dampak Kepuasan Kerja pada Kinerja Karyawan}

Kinerja dalam menjalankan fungsinya tidak berdiri sendiri tetapi berhubungan dengan kepuasan kerja. Berhadapan dengan usaha peningkatan kepuasan kerja karyawan, salah satu permasalahan dasar adalah bagaimana sebenarnya meningkatkan kepuasan kerja karyawan.

Kepuasan kerja merupakan faktor penting yang mempengaruhi kepuasan hidup karyawan karena sebagian besar waktu karyawan dipergunakan untuk bekerja sehingga Judge dalam Tondok dan Andarika (2004:36) melihat adanya hubungan erat antara kepuasan kerja, absensi, pemogokan kerja dan turnover.

Selanjutnya Hezberg dalam Tondok dan Andarika (2004:36) mengemukakan bahwa kepuasan kerja didukung oleh lima faktor yang meliputi pekerjaan, rekan kerja, gaji dan kesejahteraan karyawan, promosi dan pemimpin.

Faktor-faktor tersebut akhirnya bermuara pada kinerja yang dihasilkan. Jika 
karyawan tidak puas besar kemungkinan untuk melakukan tindakan indisipliner seperti halnya ketidakhadiran, tidak loyal dan tingginya angka keterlambatan.

Peningkatan kinerja organisasi yang optimal tidak lepas dari kepuasan kerja karyawan sebagai salah satu faktor yang menentukan kinerja organisasi. Kepentingan para pemimpin pada kepuasan kerja cenderung berpusat pada efeknya terhadap kinerja karyawan.

\section{Hipotesis}

Berdasarkan rumusan masalah, tujuan penelitian, kajian pustaka serta kerangka konseptual yang telah diuraikan sebelumnya, maka hipotesis yang diajukan dalam penelitian, adalah sebagai berikut:

1. Gaya kepemimpinan transformasional berpengaruh terhadap kepuasan kerja karyawan di Apotek Rumah Sakit Budi Kemuliaan Batam.

2. Gaya kepemimpinan transaksional berpengaruh terhadap kepuasan kerja karyawan di Apotek Rumah Sakit Budi Kemuliaan Batam.

3. Gaya kepemimpinan transformasional berpengaruh terhadap kinerja karyawan karyawan di Apotek Rumah Sakit Budi Kemuliaan Batam .

4. Gaya kepemimpinan transaksional berpengaruh terhadap kinerja karyawan di Apotek Rumah Sakit Budi Kemuliaan Batam.

5. Kepuasan kerja berpengaruh terhadap kinerja karyawan.

6. Gaya kepemimpinan transformasional berpengaruh terhadap kinerja karyawan melalui kepuasan kerja karyawan di Rumah Sakit Budi Kemuliaan Batam.

7. Gaya kepemimpinan transaksional berpengaruh terhadap kinerja karyawan melalui kepuasan kerja karyawan di Rumah Sakit Budi Kemuliaan Batam.

\section{Metode penelitian}

Berdasarkan perumusan masalah dan tujuan penelitian yang akan dicapai maka rancangan penelitian yang akan di gunakan dalam penelitian ini tergolong dalam penelitian Explanatori atau penelitian penjelasan yang melihat hubungan antara variabel-variabel penelitian dan menguji hipotesis yang telah dirumuskan sebelumnya (Masri Pangaribuan dalam Witjaksono,2003:34).

\section{Populasi}

Populasi dalam penelitian ini adalah seluruh karyawan Apotek Rumah Sakit Budi Kemuliaan Batam. Dalam penelitian ini menggunakan proses penilaian diri sendiri (self appraisal) yang dilakukan oleh perawat yang bersangkutan dan hasilnya akan dikonsultasikan dengan atasan langsung.

\section{Sampel}

Guna memenuhi azas obyektifitas maka pengambilan sampel ini akan dilakukan dengan cara Purposive Sampling, memilih sampel berdasarkan karakteristik tertentu yang dianggap mempunyai sangkut paut dengan karakteristik populasi yang sudah diketahui sebelumnya.

\section{Definisi Konsep dan Operasional Variabel Penelitian \\ Gaya Kepemimpinan Transformasional.}

Kepemimpinan transformasional (X1) yang dalam penelitian ini merupakan variabel independen adalah pengaruh pemimpin atau atasan terhadap bawahan.

Terdapat empat karakteristik kepemimpinan transformasional (Bass dalam Tondok dan Andarika,2004:38) yaitu karisma, inspirasi, stimulasi intelektual dan perhatian individual.

\section{Gaya Kepemimpinan Transaksional}

Gaya kepemimpinan transaksional (X2) dalam penelitian ini merupakan variabel independen merupakan gaya kepemimpinan yang memfokuskan perhatiannya pada transaksi interpersonal antara pemimpin 
dengan karyawan yang melibatkan hubungan pertukaran.

Menurut Bass proses kepemimpinan transaksional dapat ditunjukkan melalui sejumlah dimensi perilaku kepemimpinan yaitu contingent reward, active management by exception, dan passive management by exception.

\section{Kepuasan Kerja}

Kepuasan kerja (job satisfaction) (Z) dalam penelitian ini merupakan variabel antara (intervening) adalah keadaan emosional yang positif yang merupakan hasil dari evaluasi pengalaman kerja seseorang (Malthis dan Jackson,2006:121).

Kepuasan kerja (Z) mencakup dimensi yang bersifat intrinsik yaitu kepuasan yang diperoleh individu dari pelaksanaan pekerjaannya dan dimensi kepuasan bersifat ekstrinsik yaitu kepuasan yang didapat dari pihak eksternal.

Kepuasan kerja dalam penelitian ini diukur dengan indikator sebagai berikut: (1) Dimensi kepuasan yang bersifat intrinsik dan (2) Dimensi kepuasan yang bersifat ekstrinsik.

\section{Metode Pengumpulan Data}

Dilakukan dengan observasi, survey maupun pengumpulan dokumen yang berkaitan dengan penelitian ini. Instrumen yang digunakan dalam pengumpulan data adalah kuisioner dan wawancara.

\section{Lokasi Penelitian}

Lokasi dimana penelitian akan dilakukan adalah pada Apotek Rumah Sakit Budi Kemuliaan Batam.

\section{Uji Validitas}

Uji validitas dalam penelitian ini dilakukan dengan menggunakan analisa butir yaitu

dengan cara mengkorelasikan antar skor item (butir) dengan skor total dan dengan menggunakan alat bantu paket statistik SPSS Release13.00 for windows.

\section{Uji Reliabilitas}

Dilakukan dengan menggunakan metode Alpha Cronbach's diukur berdasarkan skala Alpha Cronbach's 0 sampai 1. Nugroho dalam Sujianto (2007:92) menyatakan bahwa reliabilitas suatu konstruk variabel dikatakan baik jika memilki Cronbach's $>0,06$.

\section{Teknik Pengujian Hipotesis dan Analisis Data Pengujian Hipotesis

$$
\text { Koefisien determinasi }
$$

dipergunakan untuk menjelaskan seberapa besar variasi variabel eksogenus mempunyai kontribusi terhadap variabel endogenus, dimana nilai $\mathrm{R} 2$ berada diantara 0 dan 1 .

\section{Teknik Analisis Data Analisis Regresi Linier Berganda}

Analisi regresi linier berganda digunakan untuk meramalkan nilai variabel terikat (Y) apabila variabel bebas minimal dua atau lebih (Umar, 2004:126), data hasil pengamatan $\mathrm{Y}$ dipengaruhi oleh variabelvariabel bebas $\mathrm{X} 1, \mathrm{X} 2, \mathrm{X} 3, \ldots \mathrm{Xn}$, sehingga rumus umum regresi linier berganda ini adalah: $\mathrm{Y}=\mathrm{a}+\mathrm{bX} 1+\mathrm{cX} 2 \ldots+\mathrm{kXk}$

\section{ANALISIS DAN PEMBAHASAN}

\section{Analisis Hasil Penelitian Uji Validitas}

Hasil uji validitas menunjukkan bahwa seluruh variabel penelitian adalah valid karena koefisien Corrected Item-Total Correlation yang terdapat pada semua butir item lebih besar dari 0,3 .

\section{Uji Reliabilitas}

Hasil uji reliabilitas pada penelitian ini menunjukkan bahwa seluruh variabel penelitian adalah reliabel, karena seluruh Alpha Cronbach dari masing-masing variabel penelitian $>0,60$. 
Analisis Regresi Linier Berganda

Analisis data dalam penelitian ini dilakukan dengan menggunakan analisis regresi linier berganda, untuk mengetahui pengaruh dari variabel independen (gaya kepemimpinan trasnformasional, gaya kepemimpinan transaksional dan kepuasan kerja) terhadap variabel dependen (kinerja karyawan). Secara spesifik model persamaan regresinya adalah $: \mathrm{Y}=\beta 0+\beta 1 \mathrm{X} 1+\beta 2 \mathrm{X} 2+$ $\beta 3 \mathrm{X} 3+\mathrm{e}$

Dari hasil penelitian tersebut akhirnya dapat ditarik suatu garis persamaan regresi sebagai berikut: $\mathrm{Y}=55,111-0,051 \mathrm{X} 1-0,098$ $\mathrm{X} 2+0,936 \mathrm{X} 3$

\section{Pengujian Hipotesis Uji Hipotesis Pertama}

$\mathrm{H} 1$ : Gaya kepemimpinan
transformasional kepuasan kerja Karyawan Asisten Apoteker di Apotek Rumah Sakit Budi Kemuliaan Batam Hasil uji nilai Sig $\mathrm{t}$ adalah 0,336 di atas taraf signifikan 0,05; maka dapat disimpulkan bahwa Hipotesis pertama ditolak, artinya tidak terdapat pengaruh yang signifikan dari gaya kepemimpinan tranformasional terhadap kepuasan kerja.

\section{Uji Hipotesis Kedua}

$\mathrm{H} 2$ : Gaya kepemimpinan transaksional berpengaruh terhadap kepuasan kerja karyawan Asisten Apoteker di Apotek Rumah Sakit Budi Kemuliaan Batam Hasil uji nilai Sig $t$ adalah 0,000 di bawah taraf signifikan 0,05 ; maka dapat disimpulkan bahwa Hipotesis kedua diterima, artinya terdapat pengaruh yang signifikan dari gaya kepemimpinan transaksional terhadap variabel kepuasan kerja.

\section{Uji Hipotesis Ketiga}

H3 : Gaya kepemimpinan transformasional berpengaruh terhadap kinerja karyawan Asisten Apoteker di Apotek Rumah Sakit Budi Kemuliaan Batam
Hasil uji nilai Sig t adalah 0,898 di atas taraf signifikan 0,05 ; maka dapat disimpulkan bahwa Hipotesis ketiga ditolak, artinya tidak terdapat pengaruh yang signifikan dari gaya kepemimpinan tranformasional terhadap kinerja karyawan.

\section{Uji Hipotesis Keempat}

H4 : Gaya kepemimpinan transaksional berpengaruh terhadap kinerja karyawan di Asisten Apoteker Apotek Rumah Sakit Budi Kemuliaan Batam

Hasil uji nilai Sig t adalah 0,280 di atas taraf signifikan 0,05; maka dapat disimpulkan bahwa Hipotesis keempat ditolak, artinya tidak terdapat pengaruh yang signifikan dari gaya kepemimpinan transaksional terhadap kinerja karyawan

\section{Uji Hipotesis Kelima}

H5 : Kepuasan kerja berpengaruh terhadap kinerja karyawan Asisten Apoteker di Apotek Rumah Sakit Budi Kemuliaan Batam. Hasil uji nilai Sig t adalah 0,000 di bawah taraf signifikan 0,05; maka dapat disimpulkan bahwa Hipotesis kelima diterima, artinya terdapat pengaruh yang signifikan dari kepuasan kerja terhadap kinerja karyawan.

\section{Uji Hipotesis Keenam}

H6 : Gaya kepemimpinan transformasional berpengaruh terhadap kinerja karyawan melalui kepuasan kerja karyawan Asisten Apoteker di Apotek Rumah Sakit Budi Kemuliaan Batam

Hasil uji nilai Sig t adalah 0,421 di atas taraf signifikan 0,05 ; maka dapat disimpulkan bahwa Hipotesis keenam ditolak, artinya tidak terdapat pengaruh yang signifikan dari gaya kepemimpinan tranformasional melalui kepuasan kerja terhadap kinerja karyawan.

\section{Uji Hipotesis Ketujuh}

H7 : Gaya kepemimpinan transaksional berpengaruh terhadap kinerja karyawanmelalui 
kepuasan kerja karyawan Asisten Apoteker di Apotek Rumah Sakit Budi Kemuliaan Batam

Hasil uji nilai Sig $\mathrm{t}$ adalah 0,000 di bawah 0,05 ; maka dapat disimpulkan bahwa: Hipotesis ketujuh diterima, artinya terdapat pengaruh yang signifikan dari gaya kepemimpinan transaksional melalui kepuasan kerja terhadap kinerja karyawan.

\section{ANALISIS DAN PEMBAHASAN}

Hasil perhitungan analisis regresi linier berganda pada penelitian ini menunjukkan bahwa gaya kepemimpinan transformasional tidak berpengaruh secara signifikan terhadap kepuasan kerja dan kinerja karyawan namun gaya kepemimpinan transaksional berpengaruh signifikan terhadap kepuasan kerja melalui kinerja karyawan.

Berdasarkan nilai koefisien korelasi (r) pada empat persamaan regresi diketahui bahwa variabel gaya kepemimpinan transaksional memiliki pengaruh yang lebih besar pada kepuasan kerja dan kinerja karyawan melalui kepuasan kerja. Sedangkan gaya kepemimpinan transformasional tidak memiliki pengaruh terhadap kepuasan kerja dan kinerja karyawan.

Dengan demikian bagi setiap pimpinan Asisten Apoteker di Apotek Rumah Sakit Budi Kemuliaan Batam akan lebih baik apabila memberikan perhatian dan perbaikan komposisi sumber daya manusianya dengan menekankan pada peningkatan hubungan interrelationshipnya dalam proses kerja dimana para pimpinan sebaiknya memperhatikan perubahan yang terjadi pada bawahannya dengan memberikan perhatian yang lebih, memberikan rasa kepercayaan dan kebanggaan serta membangun rasa hormat dan loyalitas.

Dari sisi gaya kepemimpinan transaksional, hasil penelitian menunjukkan bahwa gaya kepemimpinan transaksional berpengaruh signifikan terhadap kepuasan kerja dan berpengaruh signifikan terhadap kinerja karyawan melalui kepuasan kerja.

$\begin{array}{ccr}\text { Kepemimpinan } & \text { transformasional } \\ \text { sangat bertolak belakang dengan }\end{array}$

kepemimpinan transaksional. Kepemimpinan transaksional akan lebih berorientasi pada jangka pendek, sedangkan kepemimpinan transformasional senantiasa mendorong terciptanya kreativitas karyawan. Kontribusi kreativitas dari karyawan sangat penting artinya dalam terobosaninovasi yang dapat dilakukan perusahaan.

Untuk itu pemimpin haruslah mampu menciptakan kondisi yang kondusif untuk mencari sesuatu yang baru bukan hanya berorientasi pada pemecahan masalah. Pemimpin haruslah memilih dan mempertahankan karyawan yang kreatif dan mandiri serta memberikan peluang bagi mereka untuk berinovasi.

Penelitian ini juga menunjukkan bahwa kepuasan kerja berpengaruh signifikan terhadap kinerja karyawan. Hal ini berarti bahwa pada dasarnya seseorang dalam bekerja akan merasa nyaman dan tinggi kesetiaannya pada perusahaan apabila dalam bekerja memperoleh kepuasan kerja sesuai dengan apa yang diinginkan.

Kepuasan kerja itu sendiri adalah suatu perasaan yang dialami oleh seseorang, dimana apa yang diharapkan telah terpenuhi atau bahkan apa yang diterima melebihi apa yang diharapkan, sedangkan kerja merupakan usaha seseorang untuk mencapai tujuan dengan memperoleh pendapatan

\section{SIMPULAN DAN SARAN}

\section{Simpulan}

Berdasar hasil analisis penelitian yang telah diuraikan dapat disimpulkan: 1) Tidak terdapat pengaruh yang signifikan dari gaya kepemimpinan tranformasional terhadap kepuasan kerja. Hal ini terjadi karena fenomena di lingkungan kerja dimana kepemimpinan transformasional yang seharusnya merupakan 
faktor penentu kepuasan kerja tidak terlihat dari para pimpinan.

Pimpinan kurang memberikan rasa kepercayaan kepada bawahan, tidak dapat berkomunikasi dengan baik, kurang dalam hal memberikan inspirasi dan inisiatif serta kurang perhatian atau kurang responsif terhadap keinginan bawahan. 2) Tidak terdapat pengaruh yang signifikan dari gaya kepemimpinan tranformasional terhadap kinerja karyawan. Hal ini mungkin disebabkan karena masa kerja yang bervariasi diantara karyawan, sementara sistim rotasi karyawan belum terlalu efektif.

Hal tersebut dapat mengakibatkan kebosanan sehingga karyawan menjadi kurang kreatif dan menyebabkan produktivitas serta kinerja menurun. 3) Terdapat pengaruh yang signifikan dari gaya kepemimpinan transaksional terhadap kepuasan kerja.

Gaya kepemimpinan transaksional mampu meningkatkan kepuasan kerja karyawan karena kebutuhan karyawan atas apa yang mereka inginkan telah tercapai baik dari faktor penugasan kerja maupun dari sisi hak dan kewajiban. 4) Tidak terdapat pengaruh yang signifikan dari gaya kepemimpinan transaksional terhadap kinerja karyawan.

Hal tersebut disebabkan karena pimpinan kurang memfokuskan perhatiannya pada transaksi interpersonal antara pimpinan dengan bawahan, pimpinan kurang objektif dalam menilai kinerja bawahan, pimpinan kurang memperhatikan prestasi bawahan serta kurang mengkoordinasikan dan merencanakan pekerjaan dengan baik serta faktor leadershipnya kurang sehingga menyebabkan karyawan tidak merasa tertantang untuk lebih berprestasi dan kinerja mengalami stagnasi atau bahkan menurun.

Terdapat pengaruh yang signifikan dari kepuasan kerja terhadap kinerja karyawan. Hasil penelitian menunjukkan bahwa mereka puas terhadap pengawasan dan bimbingan pimpinan dalam pekerjaan, faktor lingkungan kerja yang baik dan sarana pendukung pekerjaan yang memadai serta faktor kesejahteraan karyawan lainnya sehingga berdampak pada peningkatan kinerja.
Tidak terdapat pengaruh yang signifikan dari gaya kepemimpinan tranformasional melalui kepuasan kerja terhadap kinerja karyawan. Hal ini disebabkan karena cara membimbing bawahan kurang baik dan kurang sesuai dengan situasi serta budaya yang sudah ada di lingkungan kerja.

Banyak karyawan yang berusia lebih tua dari pimpinan ditambah lagi dengan prestasi pimpinan yang menurut mereka kurang baik maka mereka merasa tidak cocok dan tidak sepaham dengan kebijakan dan tindakan pimpinan mereka sehingga mengakibatkan hubungan tidak harmonis.

Karyawan hanya melakukan pekerjaan secara rutin berdasarkan peraturan yang ada tanpa diikuti dengan semangat untuk maju dan berprestasi sehingga tidak berpengaruh terhadap kepuasan kerja serta tidak dapat meningkatkan kinerja karyawan. Terdapat pengaruh yang signifikan dari gaya kepemimpinan transaksional melalui kepuasan kerja terhadap kinerja karyawan.

Hal tersebut tercapai karena mereka merasa didukung oleh faktor-faktor yang meliputi pekerjaan, rekan kerja, gaji, kesejahteraan karyawan, promosi, peraturan serta sistem yang ada dan pimpinan yang menekankan pada transaksi interpersonal yang melibatkan hubungan pertukaran sehingga berdampak pada peningkatan kinerja.

\section{Saran}

Saran yang dapat diberikan adalah:

1) Diperlukan pimpinan yang memperhatikan kemampuan diri pribadinya terutama yang berkaitan dengan proses pemberian tugas serta interaksi dan perhatian terhadap bawahan.

2) Adanya usaha dari pimpinan untuk menciptakan hubungan yang harmonis diantara bawahannya hingga masing-masing individu mencapai produktivitas individual maksimum yang nantinya tercermin dari kepuasan dan kinerja karyawan.

3) Perlunya diadakan evaluasi-evaluasi yang bersifat mengukur setiap kemampuan pimpinan 
setingkat kepala ruangan atau koordinator dalam hal pelaksanaan tugas-tugas dan pendelegasian yang bersifat teknikal sehingga mampu memberikan tugas dengan baik, memberikan teladan, memiliki kreativitas dan menjaga hubungan yang lebih harmonis dengan bawahan.

4) Perlu adanya peningkatan hubungan dua arah dalam pelaksanaan tugas antara pimpinan dengan bawahan sehingga dapat

menciptakan suatu rangkaian kerja yang bisa diharapkan oleh organisasi.

5) Hasil tentang kepemimpinan transformasional dalam penelitian ini ternyata sangat bertolak belakang dengan kepemimpinan transaksional, untuk itu pemimpin haruslah mampu menciptakan kondisi yang kondusif guna mencari sesuatu yang baru dan bukan hanya berorientasi pada pemecahan masalah.

Pemimpin haruslah memilih dan mempertahankan karyawan

yang kreatif dan mandiri serta memberikan peluang bagi mereka untuk berinovasi

\section{DAFTAR PUSTAKA}

Andira \& Budiarto Subroto (2000). Pengaruh Perilaku Kepemimpinan Transformasi dan Transaksional terhadap Kinerja Karyawan Lini Depan Perusahaan Jasa. Penelitian, melalui $<$ http://digilib.unsri.ac.id/download/A ndira\%20\&\%20Budiarto.pdf>

Basuki, J. (2007). Tantangan Ilmu administrasi Publik : Paradigma baru 
Kepemimpinan Aparatur Negara. Artikel STIA LAN Jakarta, melalui $<$ http://www.stialan.ac.id/artikel\%20j \%20basuki.pdf $>[03 / 05 / 10$.

Danim, S \& Suparno (2009). Manajemen dan Kepemimpinan Transformasional Kekepalasekolahan. Jakarta. Penerbit Rineka Cipta.

Heru, T (2003). Pengaruh Kepemimpinan Transaksional dan Transformasional Terhadap Keefektifan Pemimpin, Kepuasan Bawahan, dan Upaya Ekstra Bawahan. Jurnal Akuntansi dan Manajemen Edisi April 2003, melalui $<$ http://www.stieykpn.ac.id/images/do wnloads/journal/JAM/JAM Vol 14 No 1 April 2003.pdf $>[03 / 05 / 10]$.

Kerlinger, F.N (2000). Asas-Asas Penelitian Behavioral Edisi 3. Yokyakarta. Penerbit Gajah Mada University Press.

Kerlinger, Robert \& Angelo Kinicki (2003). Perilaku Organisasi Buku Ke-1. Jakarta. Penerbit Salemba Empat.

2005. Perilaku Organisasi Buku Ke-2 Jakarta. Penerbit salemba Empat.

Laurensia, R. (2006). Pengaruh Kepemimpinan Transformasional Terhadap Kepuasan Kerja dan Komitmen Organisasi : Studi Kasus di PT Bank X Kalimantan Tengah. Jakarta. Perpustakaan MMUI.

Luthans, F. (2006). Perilaku Organisasi. Yokyakarta. Penerbit Andi.
Mangkunegara, A.A.Anwar Prabu (2005). Perilaku dan Budaya Organisasi. Bandung. Penerbit Refika Aditama.

Noegraha, A.M. (2005). Mengkaji Hubungan Antara Role, Stress Personality Types dan Kepuasan Kerja : Studi Kasus Divisi Risk Management Perbankan. Jakarta, Perpustakaan MM-UI.

Nurrachmat, S \& M. Wahyuddin (2007). Peran Kepemimpinan Transformasional , Kepemimpinan Transaksional, Komunikasi Internal dan Pengembangan Karir Terhadap Kepuasan Kerja di PT. Sumber Bengawan Plasindo Karanganyar. Jurnal Daya Saing, melalui $<$ http://eprints.ums.ac.id/806/1/Jurnal_ Daya_Saing_2_6.pdf $>$.[03/05/10].

Robbins, S.P. \& Timothy A Judge. (2008). Perilaku Organisasi Buku satu. Jakarta. Penerbit Salemba Empat.

-------(2008). Perilaku Organisasi Buku Dua. Jakarta. Penerbit Salemba Empat.

Sugiyono. (2004). Metodologi Penelitian Bisnis. Bandung. Penerbit Alfabeta.

Sujianto, A.E. (2009).Aplikasi Statistik Dengan SPSS 16.0. Jakarta. Penerbit Prestasi Pustaka.

Sulistiyani, A.T. \& Rosidah (2003). Manajemen Sumber Daya Manusia. Yokyakarta. Penerbit Graha Ilmu.

Suliyanto. (2006). Metode Riset Bisnis. Yokyakarta. Penerbit Andi. 
Tondok, M.S. \& Rita Andarika (2004).

Hubungan Antara Persepsi

Kepemimpinan Transformasional dan

Transaksional dengan Kepauasan

Kerja Karyawan. Jurnal Psyche Vol.1,

Desember 2004, melalui

$<$ http://psikologi.binadarma.ac.id/jurn

al_marcel_rita.pdf $>[03 / 05 / 10]$.

Uyanto, S.S. (2009). Perilaku Analisis Data dengan SPSS Edisi Ke-3. Yokyakarta. Penerbit Graha Ilmu.

Wahyono, S.I. (2001). Perilaku Organisasi. Yokyakarta. Penerbit Graha Ilmu.

Waworuntu, B. (2003). Determinan Kepemimpinan. Makara, Sosial Humaniora, Vol.7 No.2 Desember 2003, FISIP UI, melalui $<$ http://journal.ui.ac.id/upload/artikel/0 5-Determinan\%20KepemimpinanBobWawoR.pdf $>[03.05 / 10$

Wibowo (2008). Manajemen Kinerja. Jakarta. Penerbit Raja Grafindo Persada.

Wirawan. (2003). Kapita Selecta Teori Kepemimpinan : Pengantar untuk Praktek dan Penelitian jilid Ke-1. Jakarta. Penerbit UHAMKA Press 